\title{
APPROACHES REGARDING ENVIRONMENTAL KUZNETS CURVE IN THE EUROPEAN UNION FROM THE PERSPECTIVE OF SUSTAINABLE DEVELOPMENT
}

\author{
PANAIT, M. ${ }^{*}$ - VOICA, M. C. - RĂDULESCU, I. \\ Petroleum-Gas University of Ploiesti \\ Blvd. Bucuresti, No. 39, 100680 Ploiesti, Prahova, Romania \\ *Corresponding author \\ e-mail:mirela.matei@upg-ploiesti.ro; phone: +40-727-733-622 \\ (Received $11^{\text {th }}$ Feb 2019 ; accepted $8^{\text {th }}$ Apr 2019)
}

\begin{abstract}
The paper investigates the relation between environmental degradation and economic development. The authors focused on the situation specific to the EU-28 Member States for the timeframe 1960-2014. The study used the variables $\mathrm{CO}_{2}$ emissions, GDP per capita, imports of goods and services, exports of goods and services and energy use. The research has been divided in three distinct stages. The first stage consisted in data collection and management by analysing the existence of the unit root and determining the level at which the data is stationary. The second stage consisted in the testing Granger Causality relations between the variables for 2-5 lags. The third stage consisted in the estimation of a regression equation of the environmental Kuznets curve type. The results demonstrate the applicability of environmental Kuznets curve for the EU-28 Member States. These results can be used for design of industrial policies of these states, considering these states sustainable development goals. The public authorities are aware of the importance of environmental protection and of the correlation between environment and the economy development. The authors consider that the results of this article are an useful instrument to establish the macroeconomic policies while considering the perspective of sustainable development.
\end{abstract}

Keywords: environment, economic development, $\mathrm{CO}_{2}$ emissions, energy, imports, exports

\section{Introduction}

The Kuznets Curve has extended its applicability from the social field to the environmental field. We are witnessing the promotion of new concepts, such as the environmental Kuznets (EKC) curve or the forest transition curve (Kuznets, 1955). Simon Kuznets launched a hypothesis in the 1950s on the existence of a relationship between the level of development of a country and the income of the population. As the level of development of a country increases, in the first stage, there is a deepening of the inequality between the population incomes, as the investment opportunities are capitalized by the persons with important capital, and the migration from the villages to the cities of cheap labor force keeps the salaries at a reduced level. The mechanization of agriculture and industrialization generate international migration and a reduction in the rural population. Increasing the level of development ultimately generates revenue growth, thus recording a negative relationship between income inequality and economic development. For this reason, the Kuznets curve is shaped as a U curve.

In the first stage of industrialization, environmental issues were not a main concern either for authorities or for citizens, as everyone was focused to income (profit-making) and increasing the number of jobs. Also, the small number of strict regulations on environmental protection and, after that, the costs of protective measures, contributed to some secondary concerns and measuring of business development and diversification to environment preservation. The pressure on the environment is very high during 
industrialization, as industrial production increases are based on excessive consumption of resources and increased pollution (Marcu et al., 2016). As the level of development of a state increases, authorities, citizens and companies become more aware of the impact of their activities on the environment; environmental protection rules and regulations are strictly enforced and adhered to, and investments are made to protect the environment. In addition, factors such as income elasticity to environmental quality and changes in the composition of consumption and production (Selden and Song, 1994; Bo, 2011) have led to a decrease in pollution. Moving to a higher level of industrialization reduces environmental pressure, measured with various instruments such as pollution levels, emissions flows, resource depletion. Therefore, the pressure on the environment grows faster than the incomes in the first stages of development. The pressure will slow down as a country develops (Dinda, 2004).

The specialists concerns about the relationship between the environment and economic growth have been generated by the intensification, in the last decade of environmental degradation, with major economic, social and political implications; this has generated a change in the behaviour of companies and public institutions that have tried to identify solutions to the development of this problem (Al-Mulali et al., 2015b; Popescu et al., 2016; Andrei et al., 2017; Cristea and Dobrota, 2017). Sustainable development and corporate social responsibility are concepts accepted and promoted by authorities, companies, consumers, portfolio investors, universities, financial institutions, etc. (Ciutacu et al., 2005; Zaman, 2005; Vasile and Balan, 2008; Anghelache, 2011; Ene, 2011; Nica, 2015; Andrei et al., 2014; Sima and Georgiana, 2014; Voica et al., 2015; Ene et al., 2017; Popescu et al., 2017).

The Kuznets Curve, which was initially used for demonstrating the relation between the level of development of a country and the income of its population, has had its applicability extended, from the social field to the environmental field; we are witnessing the promotion of new concepts, such as the environmental Kuznets (EKC) curve or the forest transition curve (Kuznets, 1955).

In international scientific literature, the Kuznets curve environmental analysis was conducted, in a first phase, by researchers such as Grossman and Krueger (1991), then the issue entered into the areas of concern of international financial institutions such as the World Bank, which dedicated the 1992 report to the relationship between economic development and the environment. The 1992 report of the World Bank presents the links between the environment and economic development and draws attention to the importance of integrating environmental aspects into public policies promoted by the authorities in view of the negative environmental impacts on the quality of life, productivity and further development of a country (World Bank, 1992). Although it does not use the environmental Kuznets curve term, this report called "Development and the Environment", considers that "As incomes rise, the demand for improvements in environmental quality will increase, as will the resources available for investment". The dedication of the EKC term came a few years later, when Panayiotou (1993) named the inverted U-shaped relationship as environmental Kuznets curve (EKC).

We consider that our paper contributes to the debate on environmental degradation by estimating an EKC for the EU member states $\mathrm{CO}_{2}$ emissions over the period 19602014. The major contribution of this paper is the analysis of the relationship between $\mathrm{CO}_{2}$ emissions and the level of development of the states in the European Union. We consider that $\mathrm{CO}_{2}$ emissions is a relevant indicator in the research of the $\mathrm{EKC}$ as they 
alone are responsible for almost $60 \%$ of all greenhouse gas emissions. As we will present in the literature review section, studies made by other researchers have focused on other groups of countries and do not target the period we are considering. Our analysis was done on two levels. The first step consisted in carrying out a causal analysis of variables using the Granger causality test, and the second level consisted in identifying a regression equation based on the Kuznets theory (1955) applied to the medium-economic relationship. A series of researchers (Panayotou et al., 1999; Cole et al., 1997; Scmalensee et al., 1998) has demonstrated that the theory is valid for greenhouse gas emissions by using "environmental Kuznets curves" (EKC) term.

The novelty of our research lies in the fact that the analysis is done at the level of the 28 countries in the EU and for a period of more than 50 years. Using and interpreting data for the period 1960-2014, allows the authors to capture several stages of development specific to the EU countries, which contributes to a better substantiation of the obtained results.

The objective of this article is to determine the impact of economic development on the environment in the $28 \mathrm{EU}$ countries for the period 1960-2014. This article aims to examine the potential for convergence in the environmental policy field of the $28 \mathrm{EU}$ member states, on the assumption that they represent a specific, easily identifiable model in the environmental field, namely in the field of reducing the environmental impact. Environmental taxation and other (internal) variables imply some specific behavior in the field of environmental economics and political sector, but EU countries form a functional model with specificities that can be translated into the case of other states. In this case, we consider the possibility of substantiating a European environmental and ecological model

Even if the EU member states have gradually joined to this construction over several decades, we believe that we can have an aggregated approach of these states taking in consideration aspects like geographic proximity, the existence of European values that can be traced back to history and the obligation of fulfilling certain criteria for EU membership. Therefore, economic and political convergence is ensured at the moment a state enters the EU, thus ensuring a certain level of economic development, political and ideological harmonization.

The expansion of the EU after the fall of the communist era was a normal phenomenon, despite a period of rupture of the former Central and Eastern European countries by the capitalist system. The accession of the former communist countries was progressively achieved, as they have met the criteria imposed by the European Treaties and have proved consistency with European values by having the status of associated countries in the EU. Even though the current EU member states have had different political regimes in the past, they have undergone an intense economic development and industrialization process with negative impact on the environment. The classification and grouping of states in a model, depending on the previous political situation, influences to a relatively insignificant degree the behaviour in the field of environmental policy. Reducing sectoral environmental disparities across the $28 \mathrm{EU}$ states requires a holistic analysis of these in terms of the specificities of countries where reality variables are insignificant in the model under analysis.

The novelty of our study is to select the sum of countries, i.e. the EU countries, for which there have not been too many studies on this issue, as we will present in the literature review section, but also in the selection of variables for 1990-2014. The accession of the countries to the EU has had an impact not only on the legislative 
system, but to a large extent to the intra-community trade that have been dynamized, which is why we analyzed the imports and exports as variables. In addition, they contribute to increased production, with direct effects on the environment.

\section{Review of literature}

This section is dedicated to the literature review of the main researches regarding the implications of economic development on the environment. The link between the environment and economic development was analyzed a few decades before the EKC concept was crystallized through the famous IPAT equation $(\mathrm{I}=\mathrm{PAT})$, which established a relationship between Impact (e.g., pollution, or natural resource use) to Population, Affluence often proxied with per capita income, and Technology (Ehrlich and Holdren, 1971; Commoner, 1972).

The Growth Limit Report, developed by Dennis Meadows of the Massachusetts Institute of Technology for the Club of Rome, is a work that draws attention to the link between economic growth and environmental pollution (Carson, 2010; Bo, 2011). So, the concerns in this area are old, but the first reference work for the EKC is the study by Grossman and Krueger in 1991 that analyzed the environmental impact of North American Free Trade Agreement. Therefore, trade/ development economists have a major influence on promoting the concept of environmental Kuznets curve in the context of an international trade agreement rather than environmental/resource economists in a pollution control context (Carson, 2010). These American economists (Grossman and Krueger, 1991) analyzed the influence of the policy promoting trade and foreign investments on pollution and the rate of depletion of natural resources.

Liberalization of trade and capital flows generates:

- Increased economic activity with direct implications on the pollution (scale effect).

- Increasing the country's specialization in accordance with the comparative advantage, which will contribute to the increase of production in those sectors where the costs of pollution abatement are relatively low, and the resources will be directed to those industries that use them intensively (composition effect).

- Transfer of new technology from foreign investors and more stringent environmental protection standards by public authorities as the level of development of the host country increases (technique effect).

This first study (Grossman and Krueger, 1991) has demonstrated the link in the form of EKC between the income and sulphur dioxide $\left(\mathrm{SO}_{2}\right)$, suspended particle matter (SPM) as environmental pollutants. Other studies have also considered other pollutants that reflect air quality such as nitrogen oxide, carbon monoxide or $\mathrm{CO}_{2}$ (Selden and Song, 1994).

The environmental Kuznets curve has generated numerous debates in the literature, and it has been accepted by most specialists who have tried to measure its parameters and determine the income/inhabitant from which the level of pollution trend changes, as well as the shape of this curve considering various factors of influence. The regressions have indicated different income per capita as the inflection point for Kuznets environmental curves depends on the variables considered (Grossman and Krueger, 1991; Stern et al., 1996; Dasgupta et al., 2002). In addition, a change in the shape of the 
Kuznets curve has been observed in the sense that it is flatten downward due to the influence of factors such as economic liberalization, improvement and transparency of information, environmental protection and pollution prevention regulations from developing countries conditions based on the actions taken internationally (Dasgupta et al., 2002). So, the shape of the EKC is influenced by certain factors. In addition to the factors presented above, other researchers insist on specific elements of influence such as Inward elasticity of environmental quality demand, scale, technological and compositional effects, international trade (Dinda, 2004), but also liberalization and financial development, institutional quality (Tamazian and Rao, 2010), political and civil liberties (Shafik and Bandyopadhyay, 1992; Torras and Boyce, 1998).

The impact of economic development on the environment has been analyzed through EKG across different countries or groups of countries, with results underestimating in some cases the EKG hypothesis, as follows:

- Shahbaz et al. (2013) conducted an empirical analysis based on the 1970-2010 annual data for Turkey based on $\mathrm{CO}_{2}$ emissions and economic growth, taking in consideration the candidate status of this country to theEU. The main conclusion of the article is that an inverted U-shaped relationship is found between economic growth and $\mathrm{CO}_{2}$ emissions.

- Esteve and Tamarit (2012) confirmed the non-linearity of the link between per capita $\mathrm{CO}_{2}$ and per capita income for Spain over the period 1857-2007;

- Al-Mulali et al. (2015b) demonstrated, based on data from 1987 to 2011, that the EKC hypothesis does not exist for Vietnam because GDP and pollution have a positive relationship in the short and long run.

- Apergis and Ozturk (2015) test the environmental Kuznets curve (EKC) hypothesis for some Asian countries using data for the period 1990-2011; the main indicators used are $\mathrm{CO}_{2}$ emissions, GDP per capita, population density, land, industry shares in GDP. The result of this study was the presence of an inverted U-shape association between emissions and income per capita for 14 Asian countries.

- Li et al. (2016) used data for 28 provinces of China from 1996 to 2012 and demonstrated that the Environmental Kuznets Curve (EKC) hypothesis is verified for some of the pollutant emissions (carbon dioxide, waste water and waste solid emissions).

- Al-Mulali, Tang and Ozturk (2015a) made a study and explored the impact of economic growth (GDP), renewable energy (RE) and financial development (FD) on $\mathrm{CO}_{2}$ emissions $\left(\mathrm{CO}_{2}\right)$; the sample was composed by Latin America and Caribbean countries and data were collected for the period 1980-2010. The conclusion was that $\mathrm{CO}_{2}$ emission, GDP growth, renewable energy consumption and financial development are cointegrated and an inverted Ushaped relationship between GDP growth and $\mathrm{CO}_{2}$ emission exists.

- Cristea and Dobrota (2017) analyzed the $\mathrm{CO}_{2}$ emissions, greenhouse gas emissions (GGE), the renewable energy consumption (REC) and the consumption of biofuel (BC) in Romania in relation with the intensity of energy in economy (IEE) and the population number (PN). The authors underlined "the need to adopt Green Energy Economy in Romania, in relation to the economic activity and demographic changes...focusing mainly on energy technologies with low-carbon". 
According to our knowledge, the issue of economic development's impact on the environment at EU level has not been the subject of many scientific researches published in the mainstream in recent years. In international scientific literature, we have identified several studies published in ISI-indexed journals, the results of which are presented below.

Thus, Wawrzyniak (2018) has tested the environmental Kuznets curve in European Union countries and his econometric study was based on data for EU-28 countries in years 1990-2013. This study focuses on the impact of energy consumption, foreign direct investment, trade openness and GDP on $\mathrm{CO}_{2}$ emissions in EU states. The conclusion was that for these countries an inverted U-shaped relationship between $\mathrm{CO}_{2}$ emissions per capita and GDP per capita is observed.

Kasperowicz (2015) was interested in the study of the relationship between economic growth and $\mathrm{CO}_{2}$ emissions for $18 \mathrm{EU}$ Member States from 1995 to 2012. The analysis was based on the ECM estimation, the panel cointegration test and EGLS estimator for some European countries (including some former communist countries) and demonstrated that the long-term relationship between GDP and $\mathrm{CO}_{2}$ emissions is negative.

Armeanu et al. (2018) have explored the link between environmental pollution and economic growth in EU-28 countries; the results of the analysis confirm the EKC hypothesis in the case of emissions of sulphur oxides and emissions of nonmethane volatile organic compounds

Sterpu et al. (2018) analyzes the relationship of economic growth and energy consumption on greenhouse gas emissions for a panel of 28 countries of the European Union in the period 1990-2016. They used four macroeconomic indicators: Gross Domestic Product (GDP), Gross Inland Energy Consumption (GIC), Renewable Energy Consumption (REC), and Greenhouse Gas Emissions (GHG), in order to statistically test the EKC hypothesis. The results of the study demonstrate a non-conclusive evidence for the EKC hypothesis.

Lapinskiene et al. (2017) conducted a scientific research based on the expanded EKC model to estimate the relationship between GHG and GDP and additional factors such as energy consumption, energy taxes and R \& D. The panel used is formed by twenty EU countries, including three Baltic States, and the data are for the period 1995-2014. The main conclusion of the article is the presence of the inverse U-shaped relationship for these EU countries.

\section{Materials and methods}

In order to evaluate the relationship between $\mathrm{CO}_{2}$ emissions and the economic development, we have analyzed the following variables: $\mathrm{CO}_{2}$ emissions (metric tons per capita), GDP per capita (constant 2010 US\$), imports of goods and services (constant 2010 US\$), exports of goods and services (constant 2010 US\$) and energy use (kg of oil equivalent per capita). The research was applied for the European Union - 28 Member States. The database used for collecting the data was the World Bank, for the 1960-2014 period. For the analysis, we have opted for the World Bank database to avoid the lack of data for certain countries and the inconsistency of the data series.

First, we will make a short presentation of the average evolution for the independent variables at the EU level. We must acknowledge that different countries joined the EU at different times and so many factors influenced each country's independent variables. 
We will start by analyzing the evolution of $\mathrm{CO}_{2}$ per capita emissions. World Bank uses this definition: carbon dioxide emissions are those stemming from the burning of fossil fuels and the manufacture of cement. They include carbon dioxide produced during consumption of solid, liquid, and gas fuels and gas flaring. The source of the data is Carbon Dioxide Information Analysis Center, Environmental Sciences Division, Oak Ridge National Laboratory, Tennessee, United States.

As we can see in Figure 1, the $\mathrm{CO}_{2}$ emissions per capita started to decrease after reaching the peak of 10 metric tons per capita in 1979. Since that moment, the trend was downward. By following that trend, we can pinpoint major events in the evolution of the European countries, like 1989-1990 fall of the communism in the Eastern European member states, 1997 signing of Kyoto protocol, 2008 triggering of international financial crisis. All these events had a favourable impact on the evolution of $\mathrm{CO}_{2}$ emissions. Another important aspect is that the EU member states are reducing their $\mathrm{CO}_{2}$ per capita emissions, closing on the 1960 level.

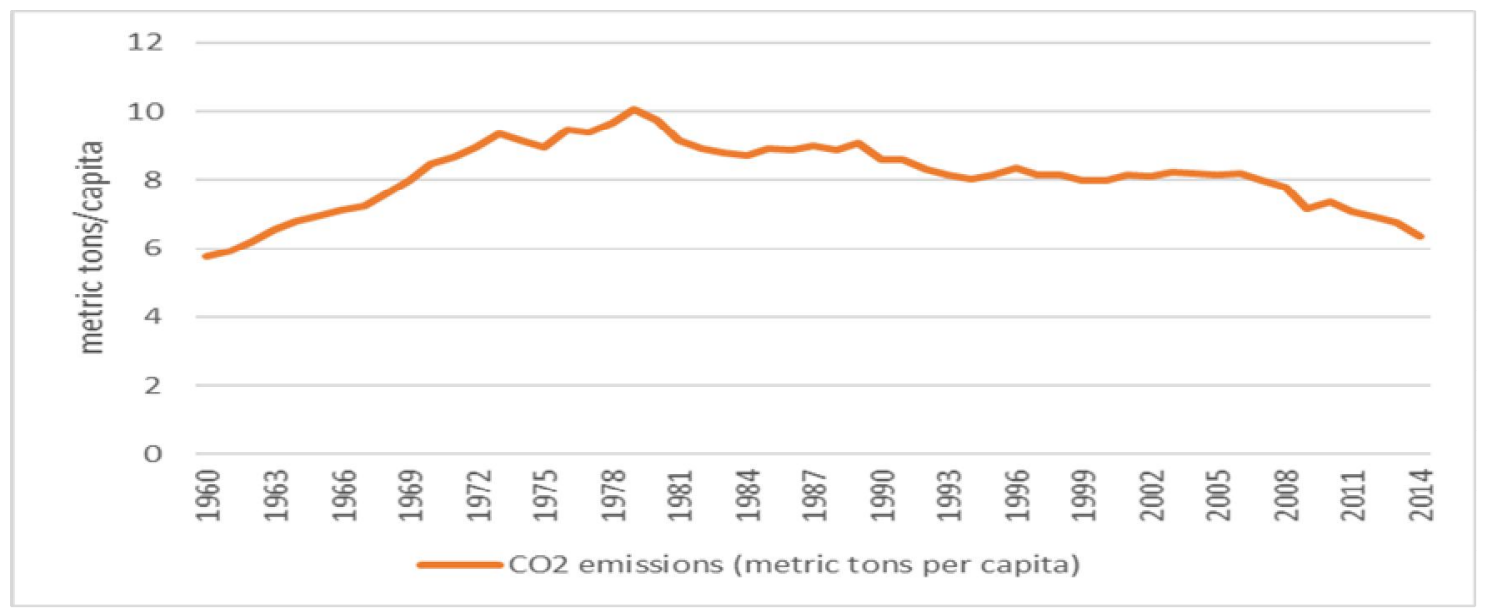

Figure 1. EU-28 average $\mathrm{CO}_{2}$ emissions (metric tons per capita) for the period 1960-2014. (Source: World Bank)

The second variable is GDP per capita. GDP per capita is gross domestic product divided by midyear population. According to World Bank, GDP is the sum of gross value added by all resident producers in the economy plus any product taxes and minus any subsidies not included in the value of the products. It is calculated without making deductions for depreciation of fabricated assets or for depletion and degradation of natural resources. Data is in constant 2010 U.S. dollars.

The third variable is represented by exports. According to the World Bank, exports of goods and services represent the value of all goods and other market services provided to the rest of the world. They include the value of merchandise, freight, insurance, transport, travel, royalties, license fees, and other services, such as communication, construction, financial, information, business, personal, and government services. They exclude compensation of employees and investment income (formerly called factor services) and transfer payments. Data is in constant 2010 U.S. dollars.

The fourth variable is represented by imports. According to the World Bank, imports of goods and services represent the value of all goods and other market services 
received from the rest of the world. They include the value of merchandise, freight, insurance, transport, travel, royalties, license fees, and other services, such as communication, construction, financial, information, business, personal, and government services. They exclude compensation of employees and investment income (formerly called factor services) and transfer payments. Data are in constant 2010 U.S. dollars.

The data for these three variables is obtained from World Bank national accounts data, and OECD National Accounts data files.

In Figure 2 we can observe the evolution of the three variables. The most relevant observation is that the imports have a higher increase than the exports. This trend became more obvious after the 1990. This can be explained by the fact that the former communist countries started their transition to the open market. The GDP/capita had a steady trend in the analyzed period and, only after the financial crisis of 2008, the ascending trend of GDP/capita slowed down. Like in the case of GDP/capita, imports and exports also have been influenced by the financial crisis.

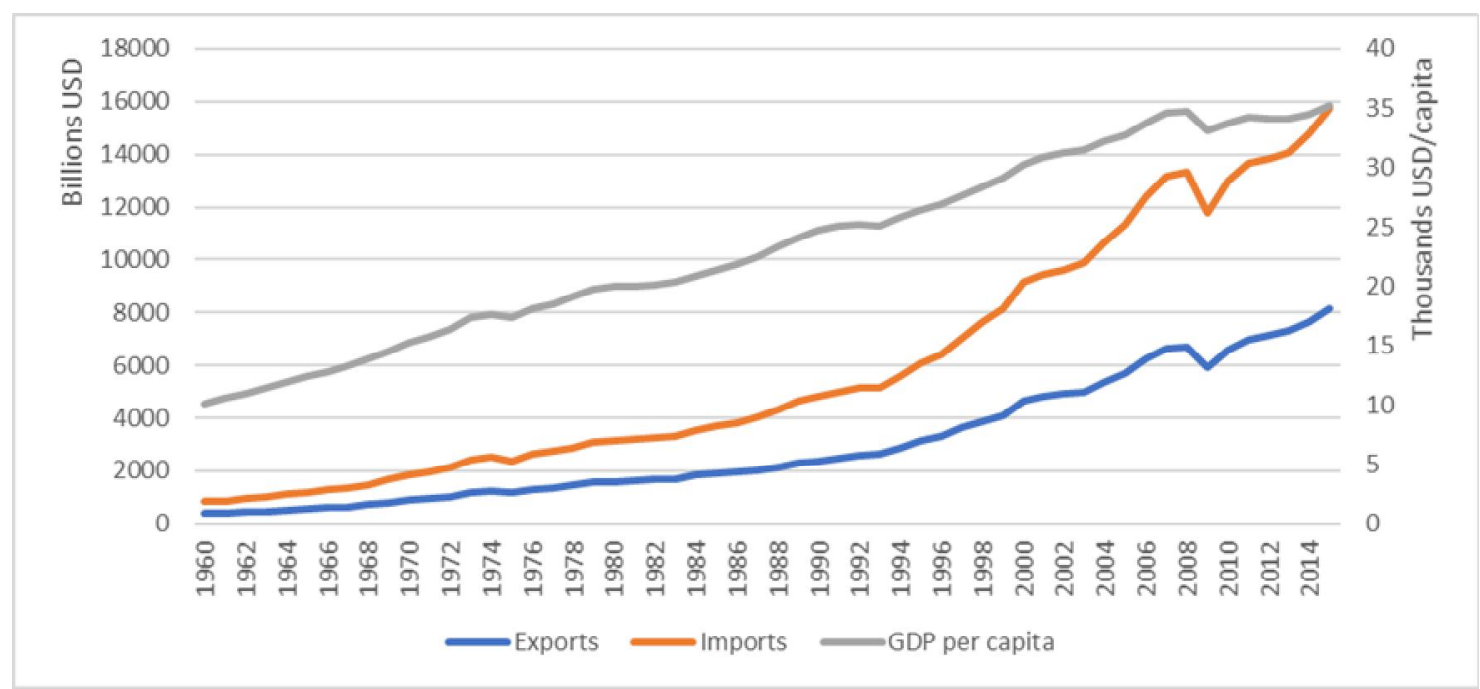

Figure 2. EU-28 average GDP/capita, exports and imports for the period 1960-2014 (constant US \$ 2010). (Source: World Bank)

The fifth variable presented in Figure 3 is energy use. According to the World Bank, energy use refers to use of primary energy before transformation to other end-use fuels, which is equal to indigenous production plus imports and stock changes, minus exports and fuels supplied to ships and aircraft engaged in international transport. The source of the data is IEA Statistics (C) OECD/IEA 2014. 


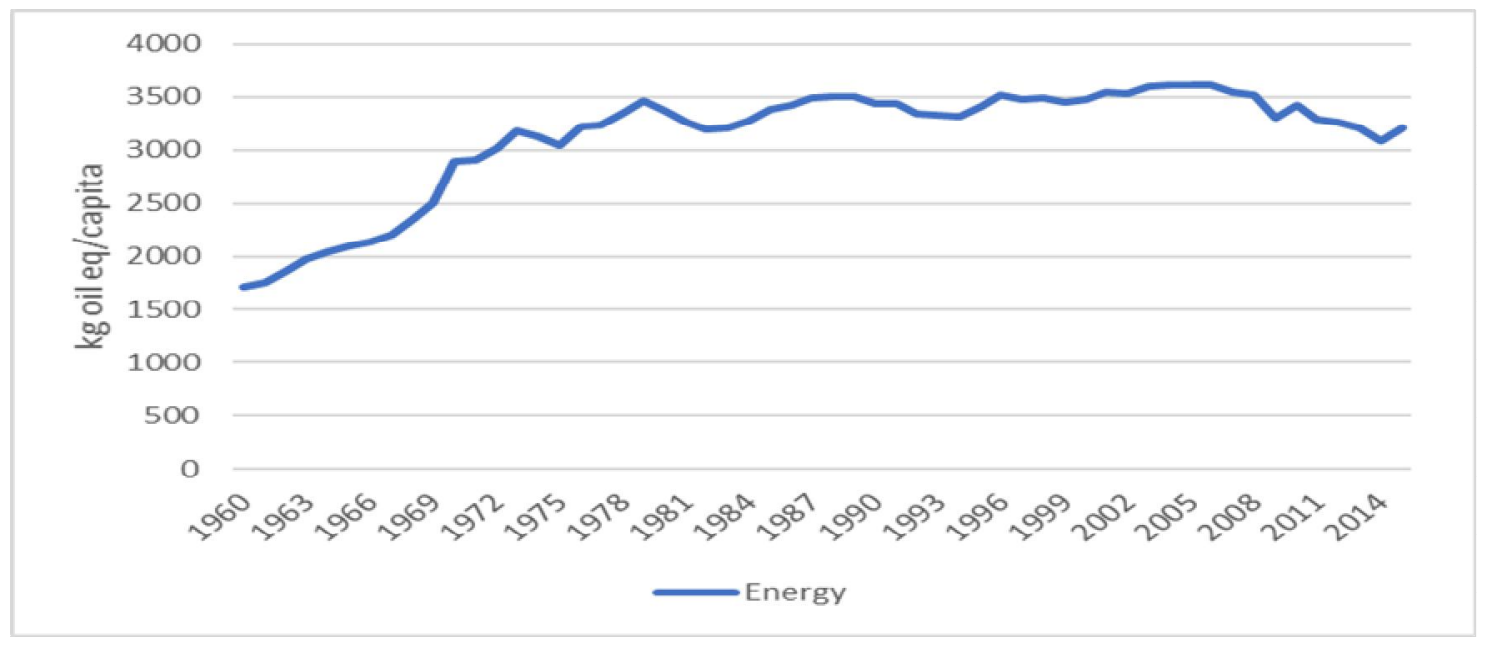

Figure 3. EU-28 average energy use ( $\mathrm{kg}$ of oil equivalent per capita) for the period 1960-2014. (Source: World Bank)

The energy use in the analyzed period shoved an ascending trend until 1979, and after that the evolution was constant until 2008, when the trend changed direction.

The research has been divided in three distinct stages. The first stage consisted in data collection and treatment by analyzing the existence of the unit root and determining the level at which the data is stationary. The second stage consisted in the testing of Granger Causality relations between the variables for 2-5 lags. The third stage consisted in the estimation of a regression equation of the environmental Kuznets curve type.

Unit root was tested using Levin et al. (2002) (LLC) test, ADF Fisher-type test, Im, Pesaran and Shin (2003) W-stat and PP Fisher-type test (Choi, 2001; Maddala, 1999). For a better understanding of these tests forward we provide a review of them (Kuzume, 2005).

Levin et al. (2002) tested the null hypothesis $H_{0}: \delta=0$ compared with the alternative hypothesis $H_{0}: \delta<0$, using:

$$
\Delta q_{i, t}=\alpha_{m i} d_{m t}+\delta q_{i, t-1}+\sum_{k=1}^{p} \gamma_{k} \Delta q_{i, t-k}+\epsilon_{i, t}
$$

where $d_{m t}$ denotes the determinant parts and $\epsilon_{i, t}$ is considered to be independent distributed among $I$ and $t$, with $i=1, \ldots, N$ and $t=1, \ldots, T$. Immediately after the normalized interference and the correspondent of the pseudo ratio $t$ of cumulated OLS estimations of $\delta$ in Equation 1 are properly normalized, the convergence at a standard limit of normal distribution is achieved as $N \rightarrow \infty, T \rightarrow \infty$ so that $\sqrt{N} / T \rightarrow 0$.

Im et al. (2003) test is built on the estimation (Eq. l) but changing $\delta$ with $\delta_{i}$. The null hypothesis is $H_{0}: \delta=0 V_{i}$, while the alternative hypothesis is $H_{1}: \delta<0 i=1 \ldots N_{1}$; $\delta_{i}=0, i=N_{1}+1, \ldots, N$. So, the null hypothesis is rejected if the is a subset $\left(N_{1}\right)$ of stationary data. First test is the standardized group-mean Lagrange Multiplier (LM) bar test statistic

$$
\psi_{\overline{L M}}=\frac{\sqrt{N\left[\overline{L M}-N^{-1} \sum_{i=1}^{N} E\left(L M_{i}\right)\right]}}{\sqrt{N^{-1} \sum_{i=1}^{N} \operatorname{Var}\left(L M_{i}\right)}}
$$


with $\overline{L M}=N^{-1} \sum_{i=1}^{N} L M_{i}$, where $L M_{i}$ denotes the individual LM tests for testing $\delta_{i}=$ 0 in Equation 1, and $E\left(L M_{i}\right)$ and $\operatorname{Var}\left(L M_{i}\right)$ are achieved through Monte Carlo simulation.

The next test is the standardized group mean $t$ bar test statistic $\psi_{\bar{t}}$, with a similar expression like Equation 2, replacing $\overline{L M}$ and $L M_{i}$ with $\bar{t}$ and $t_{i}$.

We defined $\bar{t}=N^{-1} \sum_{i=1}^{N} t_{i}$, where $t_{i}$ denotes the individual pseudo $t$ ratio for testing $\delta_{i}=0$ in Equation 2, and $E\left(t_{i}\right)$ and $\operatorname{Var}\left(t_{i}\right)$ are computed using the Monte Carlo simulation. In Im et al. (2003), because $N \rightarrow \infty, T \rightarrow \infty$ and $N / T \rightarrow k$, both statistic tests for distribution limitation are standard normal.

Fisher-ADF and Fisher-PP test are an alternative approach to test for unit root in panel data that uses the results of Fisher (1932) in testing for combined $p$ values of the individual test of unit root, as they were propose by Maddala and Wu (1999) and Choi (2001).

If $\pi_{i}$ is the $p$ value of any individual unit root test for transversal section $i$, then, under the nullity of unit root for every transversal section $N$, we have the asymptotic result:

$$
-2 \sum_{i=1}^{N} \log \left(\pi_{i}\right) \rightarrow \chi_{2 N}^{2}
$$

Choi (2001) proves that:

$$
Z=\frac{1}{\sqrt{N}} \sum_{i=1}^{N} \Phi^{-1}\left(\pi_{i}\right) \rightarrow N(0,1)
$$

where $\Phi^{-1}$ is the inverse of the standard normal distributed cumulative function.

For the unit root tests, we used Schwarz info criterion, Newey-Vest automatic band width selection and Bartlett kernel.

In order to test the causality relation between the variables, we start from the Granger (1969) Hypothesis that asked how much of the variable y may be deduced from the past values of $\mathrm{y}$ and then asked if by adding the past values of $\mathrm{x}$ he can obtain a better approximation of $\mathrm{y}$. A variable $\mathrm{y}$ is Granger caused by $\mathrm{x}$ when $\mathrm{x}$ improves the predictive capacity of $\mathrm{y}$, or when the past coefficients of variable $\mathrm{x}$ are statistically significant. We must acknowledge that a two-way causality is a frequent case when $\mathrm{x}$ Granger causes y and y Granger causes $\mathrm{x}$.

In order to apply a Granger causality, test we must specify the lag length $l$. Usually it is better to use more lags in order to get the relevant information form the past. In our study we tested the Granger causality relation between the variables for 2, 3, 4, and 5 .

After establishing the lag length, we will estimate a bivariate regression of the form:

$$
\begin{aligned}
& y_{t}=\alpha_{0}+\alpha_{1} y_{t+1}+\cdots+\alpha_{l} y_{t-l}+\beta_{1} x_{t+1}+\cdots+\beta_{l} x_{t-l}+\varepsilon_{t} \\
& x_{t}=\alpha_{0}+\alpha_{1} x_{t+1}+\cdots+\alpha_{l} x_{t-l}+\beta_{1} y_{t+1}+\cdots+\beta_{l} y_{t-l}+\mu_{t}
\end{aligned}
$$


for each possible pair of $(\mathrm{x}, \mathrm{y})$ series of the group. F-statistic reported values are the Wald statistics for the consolidated hypotheses:

$$
\beta_{1}=\beta_{2}=\cdots=\beta_{l}=0
$$

for each equation, the null hypothesis is that $x$ does not Granger cause $y$ in the first regression and $y$ does not Granger cause $x$ in the second regression.

In order to estimate the regression equation, we started from the linear regression using the OLS method with panel data of the form:

$$
Y_{i t}=f\left(X_{i t}, \beta\right)+\delta_{i}+\gamma_{t}+\epsilon_{i t}
$$

This specific case implies a conditional mean linear specification so that we achieve:

$$
Y_{i t}=\alpha+X_{i t}^{\prime} \beta+\delta_{i}+\gamma_{t}+\epsilon_{i t}
$$

where $Y_{i t}$ is the dependent variable, $X_{i t}$ is a regressor vector $k$ and $\epsilon_{i t}$ error terms for $i=1,2, \ldots, M$ transversal units, observed for the dated periods $t=1,2, \ldots, T$. $\alpha$ is the general constant of the model while $\delta_{i}$ and $\gamma_{t}$ represents the effects specific to transversal section or time period.

By introducing the variables specific to our study and of EKC conditions in Equation 9 we achieve a regression of the form:

$$
\ln C O 2=\beta_{0}+\beta_{1} \ln G D P+\beta_{2} \ln G D P^{2}+\beta_{3} \ln E N E R G Y+\beta_{4} \ln E X P+\beta_{5} \ln I M P+\epsilon(\text { Eq. } 10)
$$

where: $\mathrm{CO}_{2}-\mathrm{CO}_{2}$ emissions (metric tons per capita), GDP - GDP per capita (constant 2010 US\$), ENERGY - Energy use (kg of oil equivalent per capita), IMP - Imports of goods and services (constant 2010 US\$), EXP - Exports of goods and services (constant $2010 \mathrm{US} \$$ ), $\beta_{0}, \beta_{1}, \beta_{2}, \beta_{3}, \beta_{4}, \beta_{5}$ - regression coefficients, $\epsilon$ - estimation error.

\section{Results and discussions}

\section{Unit root tests}

In this part, we present the summary statistics for each variable in Table 1 and we have tested the variables for unit root in order to find the correct level at which the data has achieved stationarity. Because we are working with monetary units, first, we will apply logarithms to the variables and after will proceed with the unit root tests. For unit root testing we use Augmented Dickey-Fuller Fisher Chi-square test, Phillips-Perron Fischer Chi-square test, Im, Pesaran and Shin W-stat test and Levin, Lin \& Chu t* test. Probabilities for Fisher tests are computed using an asymptotic Chi-square distribution. All other tests assume asymptotic normality. The results of the unit root test are presented in Table2.

As we can see in Table 2, the $\mathrm{CO}_{2}$ emissions (CO2) are not stationary at level so we proceed to $1^{\text {st }}$ difference in order to achieve a stationary series. In the case of GDP per capita (GDP), energy use (ENERGY), imports of goods and services (IMP) and 
exports of goods and services (EXP) they are stationary at level so there is no need for the first difference in their case. After the unit root testing we can proceed to the next steps of pair wise Granger causality tests and estimating the regression equation.

Table 1. Summary statistics

\begin{tabular}{c|c|c|c|c|c}
\hline Variable & CO2 & GDP & ENERGY & IMP & EXP \\
\hline Mean & 8.568981 & 24186.28 & 3350.261 & $1.15 \mathrm{E}+11$ & $1.17 \mathrm{E}+11$ \\
Median & 8.342206 & 24596.83 & 3449.615 & $1.05 \mathrm{E}+11$ & $1.11 \mathrm{E}+11$ \\
Maximum & 10.61663 & 31640.55 & 3817.867 & $2.43 \mathrm{E}+11$ & $2.61 \mathrm{E}+11$ \\
Minimum & 6.536127 & 13653.27 & 2188.12 & $2.12 \mathrm{E}+10$ & $2.07 \mathrm{E}+10$ \\
Std. Dev. & 1.010208 & 4735.476 & 423.3341 & $6.47 \mathrm{E}+10$ & $6.79 \mathrm{E}+10$ \\
Skewness & 0.076213 & -0.49537 & -1.43333 & 0.518412 & 0.536285 \\
Kurtosis & 2.193371 & 2.49813 & 4.007721 & 2.330016 & 2.397456 \\
\hline
\end{tabular}

Table 2. Unit root tests results

\begin{tabular}{c|c|c|c|c|c}
\hline \multirow{2}{*}{ Variable } & Test & \multicolumn{2}{|c|}{ Level } & \multicolumn{2}{c}{$\mathbf{1}^{\text {st }}$ difference } \\
\cline { 3 - 6 } & & Statistic & Prob & Statistic & Prob \\
\hline \multirow{5}{*}{ CO2 } & ADF Fischer Chi-square & 42.5443 & 0.9076 & 630.455 & 0.0000 \\
& PP Fischer Chi-square & 55.2986 & 0.5014 & 634.417 & 0.0000 \\
& Im, Pesaran and Shin W-stat & -0.55240 & 0.2903 & -25.3097 & 0.0000 \\
& Levin, Lin \& Chu t* & -0.74218 & 0.2290 & -32.9086 & 0.0000 \\
\hline \multirow{5}{*}{ GDP } & ADF Fischer Chi-square & 140.743 & 0.0000 & - & - \\
& PP Fischer Chi-square & 131.884 & 0.0000 & - & - \\
& Im, Pesaran and Shin W-stat & -7.15187 & 0.0000 & - & - \\
& Levin, Lin \& Chu t* & -12.5479 & 0.0000 & - & - \\
\hline \multirow{5}{*}{ ENERGY } & ADF Fischer Chi-square & 266.800 & 0.0000 & - & - \\
& PP Fischer Chi-square & 266.800 & 0.0000 & - & - \\
& Im, Pesaran and Shin W-stat & -12.7320 & 0.0000 & - & - \\
& Levin, Lin \& Chu t* & -16.0019 & 0.0000 & - & - \\
\hline \multirow{5}{*}{ IMP } & ADF Fischer Chi-square & 115.479 & 0.0000 & - & - \\
& PP Fischer Chi-square & 95.6684 & 0.0008 & - & - \\
& Im, Pesaran and Shin W-stat & -5.79535 & 0.0000 & - & - \\
& Levin, Lin \& Chu t* & -13.1799 & 0.0000 & - & - \\
\hline \multirow{5}{*}{ EXP } & ADF Fischer Chi-square & 106.632 & 0.0001 & - & - \\
& PP Fischer Chi-square & 92.0854 & 0.0017 & - & - \\
& Im, Pesaran and Shin W-stat & -5.28681 & 0.0000 & - & - \\
& Levin, Lin \& Chu t* & -12.9788 & 0.0000 & - & - \\
\hline
\end{tabular}

\section{Granger causality test}

As we already explained, the pair wise Granger causality test consists in determining if avariable $y$ is Granger-caused by $x$ when $x$ improves the prediction of $y$, or when the coefficients of the lagged $x$ are statistically significant. We must acknowledge that a two-way causation is a frequent case in which $x$ Granger causes $y$ and $y$ Granger 
causes $x$. In Table 3 we have the results of the pair wise Granger causality tests for our variables for a lag range from 2 to 5 .

By analyzing the data from Table 3 we observe that between the pairs of variables there are two-way Granger causality of a high level of statistical significance at a level of $1 \%$. Another interesting thing observed is that the significance tends to be lower only for a smaller number of lags and as we past lag three all pairs have a two-way Granger causality significance lower than $1 \%$, which is a logic evolution as time must pass before the evolution from one variable fully affect the evolution of the other variables.

Table 3. Pair wise Granger causality tests

\begin{tabular}{|c|c|c|c|c|c|}
\hline \multirow{2}{*}{ Pair } & Lags & 2 & 3 & 4 & 5 \\
\hline & Null hypothesis & F-statistic & F-statistic & F-statistic & F-statistic \\
\hline \multirow{2}{*}{ GDP-CO2 } & $\begin{array}{l}\text { GDP does not Granger } \\
\text { Cause } \mathrm{CO} 2\end{array}$ & $139.360^{* * *}$ & $140.541^{* * *}$ & $108.515^{* * *}$ & $106.431^{* * *}$ \\
\hline & $\begin{array}{l}\mathrm{CO} 2 \text { does not Granger } \\
\text { Cause GDP }\end{array}$ & $2.28528^{*}$ & $13.0574^{* * * *}$ & $15.5907^{* * *}$ & $13.6148^{* * * *}$ \\
\hline \multirow{2}{*}{ EXP-CO2 } & $\begin{array}{l}\text { EXP does not Granger } \\
\text { Cause } \mathrm{CO} 2\end{array}$ & $174.258^{* * *}$ & $182.581^{* * * *}$ & $138.809^{* * * *}$ & $110.860^{* * *}$ \\
\hline & $\begin{array}{c}\mathrm{CO}_{2} \text { does not Granger } \\
\text { Cause EXP }\end{array}$ & $5.80083^{* * *}$ & $5.77247^{* * * *}$ & $3.62445^{* * * *}$ & $3.52626^{* * * *}$ \\
\hline \multirow{2}{*}{ ENERGY-CO2 } & $\begin{array}{l}\text { ENERGY does not } \\
\text { Granger Cause CO2 }\end{array}$ & $273.439^{* * *}$ & $178.078^{* * * *}$ & $154.679^{* * * *}$ & $136.132^{* * *}$ \\
\hline & $\begin{array}{l}\mathrm{CO} 2 \text { does not Granger } \\
\text { Cause ENERGY }\end{array}$ & $97.6253^{* * * *}$ & $84.7030^{* * *}$ & $91.0687^{* * *}$ & $79.1074^{* * * *}$ \\
\hline \multirow{2}{*}{ IMP-CO2 } & $\begin{array}{l}\text { IMP does not Granger } \\
\text { Cause } \mathrm{CO}_{2}\end{array}$ & $165.690^{* * * *}$ & $163.380^{* * *}$ & $130.129^{* * * *}$ & $105.108^{* * * *}$ \\
\hline & $\begin{array}{c}\mathrm{CO}_{2} \text { does not Granger } \\
\text { Cause IMP }\end{array}$ & $10.3148^{* * * *}$ & $10.8472^{* * * *}$ & $5.12759^{* * * *}$ & $13.2843^{* * * *}$ \\
\hline \multirow{2}{*}{ EXP-GDP } & $\begin{array}{l}\text { EXP does not Granger } \\
\text { Cause GDP }\end{array}$ & $87.9991^{* * *}$ & $79.5266^{* * * *}$ & $68.5079^{* * * *}$ & $55.7066^{* * *}$ \\
\hline & $\begin{array}{l}\text { GDP does not Granger } \\
\text { Cause EXP }\end{array}$ & $84.2777^{* * * * k}$ & $76.2382^{* * * *}$ & $66.7145^{* * * *}$ & $62.2858^{* * * *}$ \\
\hline \multirow{2}{*}{ ENERGY-GDP } & $\begin{array}{l}\text { ENERGY does not } \\
\text { Granger Cause GDP }\end{array}$ & $4.19931^{* *}$ & $3.02615^{* *}$ & $27.7061^{* * * *}$ & $22.5724^{* * *}$ \\
\hline & $\begin{array}{l}\text { GDP does not Granger } \\
\text { Cause ENERGY }\end{array}$ & $3.68748^{* *}$ & $22.9844^{* * * *}$ & $18.3863^{* * * *}$ & $28.0118^{* * *}$ \\
\hline \multirow{2}{*}{ IMP-GDP } & $\begin{array}{l}\text { IMP does not Granger } \\
\text { Cause GDP }\end{array}$ & $75.7645^{* * *}$ & $78.0957^{* * *}$ & $60.0087^{* * * *}$ & $47.0374^{* * * *}$ \\
\hline & $\begin{array}{l}\text { GDP does not Granger } \\
\text { Cause IMP }\end{array}$ & $91.3735^{* * *}$ & $72.4171^{* * * *}$ & $56.2888^{* * * *}$ & $44.1893^{* * * *}$ \\
\hline \multirow{2}{*}{ ENERGY-EXP } & $\begin{array}{l}\text { ENERGY does not } \\
\text { Granger Cause EXP }\end{array}$ & $70.3780^{* * * *}$ & $54.6008^{* * * *}$ & $50.6015^{* * * *}$ & $49.6728^{* * * *}$ \\
\hline & $\begin{array}{l}\text { EXP does not Granger } \\
\text { Cause ENERGY }\end{array}$ & $23.7478^{* * * *}$ & $59.7225^{* * * *}$ & $51.9012^{* * * *}$ & $67.0064^{* * * *}$ \\
\hline \multirow{2}{*}{ IMP-EXP } & $\begin{array}{l}\text { IMP does not Granger } \\
\text { Cause EXP }\end{array}$ & $7.70112^{* * *}$ & $6.59588^{* * *}$ & $16.1623^{* * * *}$ & $43.6035^{* * * *}$ \\
\hline & $\begin{array}{l}\text { EXP does not Granger } \\
\text { Cause IMP }\end{array}$ & $28.8718^{* * *}$ & $26.1496^{* * *}$ & $31.4193^{* * *}$ & $40.9379^{* * * *}$ \\
\hline IMP-ENERGY & $\begin{array}{l}\text { IMP does not Granger } \\
\text { Cause ENERGY }\end{array}$ & $17.1906^{* * * *}$ & $36.4039^{* * * *}$ & $31.1759^{* * * *}$ & $33.6088^{* * * *}$ \\
\hline
\end{tabular}




\begin{tabular}{l|l|l|l|l|l} 
ENERGY does not & $\mathbf{8 8 . 8 4 6 1}^{* * *}$ & $\mathbf{6 8 . 0 7 3 9}^{* * *}$ & $\mathbf{6 2 . 9 3 8 7}^{* * * *}$ & $\mathbf{6 6 . 0 6 4 2}^{* * * *}$ \\
\hline Granger Cause IMP & $\mathbf{6 r}^{*}$
\end{tabular}

"significance at $10 \% ;{ }^{* *}$ significance at $5 \% ;{ }^{* * *}$ significance at $1 \%$

As we can observe from the data presented in Table 3, the $\mathrm{CO}_{2}$ has two-way relations with the independent variables from the study. These relations have been explained in previous studies (Pirlogea and Cicea, 2012; Allen, 2012; Su and Ang, 2016; López, et al., 2013) and our results provide similar conclusions. The $\mathrm{CO}_{2}$ emissions have always been linked to the level of development, quantified by the GDP per capita. As a country reaches a higher level of development, its technological endowment changes from high pollution generating machinery, to environmentally friendly ones. This happens through the change of policy towards $\mathrm{CO}_{2}$ emissions. The increase of GDP is linked with intensified activity on the international market quantified in our study by the imports and exports. Our results support this link, as the growth of $\mathrm{CO}_{2}$ emissions is generated by the industrial production and other sectors growth. This growth generates, on one hand, a need for raw materials and intermediate goods, which takes the form of imports, and, on the other hand, the need to sell the produced goods to new markets which takes the form of exports. Another problem that must be acknowledged in respect to the international trade is the shift of $\mathrm{CO}_{2}$ emissions from one country to another through imports and exports. As a country reaches a higher level of development and the pressure regarding the $\mathrm{CO}_{2}$ emissions from policymakers, NGOs or other forms increases, there is the possibility to import the goods whose production generates high levels of $\mathrm{CO}_{2}$ emissions. In this case, we have only a false reduction of $\mathrm{CO}_{2}$ emissions, as the quantity of $\mathrm{CO}_{2}$ emissions is shifted from the importing country to the exporting one, usually a developing country where there is a lower pressure regarding the $\mathrm{CO}_{2}$ emissions and a higher demand for development. The link between $\mathrm{CO}_{2}$ and energy consumption is one of the easiest to explain as the production of energy generates the largest amount of $\mathrm{CO}_{2}$ apart from the energy produced from renewable sources, but even here the topic is under debate.

\section{Environmental Kuznets curves for EU}

We chose the EU for our study because the EU took a lot of steps toward reducing the $\mathrm{CO}_{2}$ emissions and it has a proactive approach on the climate change issue that troubles the world leaders' minds. In this stage, we are going use the EKC model to estimate an equation with the $\mathrm{CO}_{2}$ emissions as the dependent variable, and GDP/capita, energy consumption, imports and exports, as the independent variables. Previous studies (Apergis and Ozturk, 2015; Li et al., 2016; Al-Mulali et al., 2015a) added different variables to the model in order to better estimate the evolution of the dependent variable. For our estimation, we used the panel least squares method with a sample of 53 periods, between 1961 and 2013 and 28 cross-sections for each of the Member States, resulting a number 1484 observations.

In Table 4 we have presented the results for the regression coefficients and forward the regression equation will be of the form:

$$
\begin{aligned}
& \ln C O 2=35.89-7.42 \ln G D P+0.36 \ln G D P^{2}+0.27 \ln E N E R G Y-0.17 \ln E X P+ \\
& 0.18 \ln I M P
\end{aligned}
$$


Our regression equation has an R-square value of 0.30 which means the model can explain only a part of the evolution of the $\mathrm{CO}_{2}$, and a value of 1.94 for the DurbinWatson test. The values of the coefficients provide us important information regarding the influence of each independent variable on the $\mathrm{CO}_{2}$ evolution.

Table 4. EKC regression coefficients

\begin{tabular}{c|c|c|c|c}
\hline Variable & Coefficient & Std. error & t-statistic & Prob. \\
\hline C & 35.88499 & 3.068164 & 11.69592 & 0.0000 \\
GDP & -7.420802 & 0.635589 & -11.67548 & 0.0000 \\
GDP $^{2}$ & 0.360973 & 0.031047 & 11.62684 & 0.0000 \\
ENERGY & 0.266519 & 0.022969 & 11.60349 & 0.0000 \\
EXP & -0.174257 & 0.026417 & -6.596447 & 0.0000 \\
IMP & 0.176767 & 0.028129 & 6.284131 & 0.0000 \\
\hline
\end{tabular}

According to EKC, the coefficient of GDP should be positive, while the coefficient of $\mathrm{GDP}^{2}$ should be negative. In our results, we observe that the coefficients do not have the same signs as the EKC and the sign of GDP is negative while the sign of GDP ${ }^{2}$ is positive.

The plus sign of the per capita energy consumption coefficient confirms that as the energy consumption increases, the $\mathrm{CO}_{2}$ emission will follow a similar trend, fact discovered in previous studies (Du et al., 2012; Shahbaz et al., 2012; Jalil and Mahmud, 2009; Saboori and Sulaiman, 2013; Andrei et al., 2017). The $\mathrm{CO}_{2}$ emissions have always been in relation with the energy consumption as its production generates a high percentage of the total amount of greenhouse gas emissions. The only way to reduce the emissions generated from energy production is the technological conversion to renewable sources and the general adoption of clean technologies. The main problem of renewable energy is that they also have an impact on the environment as the materials and the production process of the renewable sources power plants generates greenhouse gases. Also, they impact the environment by affecting the landscape and in some cases negatively impacting the food production by converting the land used for food production to land used for energy plants in the case of biomass, biogas and biodiesel.

The exports have a negative impact on $\mathrm{CO}_{2}$ emissions. There can be many explanations about this relation and this depends on the level of development of each country, the structure of the industrial endowment. As an example, we can say that the exports may have a negative impact on $\mathrm{CO}_{2}$ emissions in the case of a country which exports raw materials or low fabrication ones. Also, a country could execute only some operations of the supply chain with a low level of emissions, and then export them to continue production in countries with a less strict regulation on environment.

In the case of imports, the same examples are available but from the opposed side as importing raw materials and executing the high $\mathrm{CO}_{2}$ emitting activities from the production chain of goods.

We must acknowledge that the model has its limitations and even Kuznets had his caveats regarding the original model mainly regarding the fragility of the data and even if the data turned out to be valid, it pertained to an extremely limited period and to exceptional historical experiences (Fogel, 1987). 
Starting from this statement, we further stress that there were gaps in the availability of data, especially in the case of former communist countries. Also, there is a development gap between the older members of the EU and the newcomers which generated real convergence problem acknowledge by the EU and which was discussed on many occasions. Although the problem is well known, little has been done to reduce the gap and many times we found ourselves talking about a two speed European Union or a center-periphery relation between groups of member states.

\section{Conclusions}

The sample of countries chosen for this analysis was based on several considerations. The EU countries are characterized by high growth rates, and commercial and financial liberalization has a bivalent impact on the environment. On the one hand, the accession of Central and Eastern European countries can lead to a significant increase in the production of domestic companies and the attraction of important foreign capital flows, which can have a negative impact on the environment. On the other hand, environmental protection is a constant preoccupation of the European authorities, and the accession to the EU supposes the transposition of the European directives in the national legislation (Marcu et al., 2015). The liberalization of trade flows between Member States is an important factor of economic development (fact emphasized in the very first article dedicated to the $\mathrm{EKC}$ ), which has a strong impact on the environment.

More and more specialists have drawn attention to the modification of the EKC in terms of its flattening, given that the environmental protection regulations adopted in the developed countries have been rapidly copied by the authorities in the developing countries. In addition, international efforts by institutions such as the United Nations or the OECD have had their effects, and their concerns about environmental protection, sustainable development and corporate social responsibility have been promoted both in developed countries and in developing countries. The levers by which the negative impact of economic activity on the environment can be limited have also multiplied. For example, the Kyoto Protocol of the United Nations Framework Convention on Climate Change was signed in 1997 (and entered into force in February 2005) and the parties committed to reducing greenhouse gas (GHG) emissions in line with specific targets. It is the first step towards a truly global emission reduction regime. In addition, the principles of sustainable development or social responsibility are followed by companies, financial institutions and portfolio investors.

The free movement of capital in the EU has generated robust financial flows in new member countries from both EU-developed companies and companies from other host countries that wanted to have fast access to the entire European market. Transferred technology has not always been last generation and environment friendly, which is why the impact of foreign direct investment on the environment in the host country, in some cases, may be negative.

The presence of large European financial groups in the new member states also determines the development of local financial markets, as well as the promotion of sustainable financing techniques for local companies. More and more banks are concerned not only with the economic impact of the investment projects they finance, but also with the environmental impact, which is why the financing of green investments is a reality in these countries as well. 
The results of the study show us that the EU countries followed the Kuznets environmental curve; however, the multitude of levels of development may interfere with the end conclusion. The EU has its core problems regarding the real convergence of the new member states, fact highlighted by the latest talks about a two-speed union.

The data used for the study has some gaps in the case of the former communist countries data from before 1990, when these countries started the transition towards democracy. Also, in some of these countries, the reduction of $\mathrm{CO}_{2}$ emissions was the result of industrial activity reduction generated by the restructuring or closing of entire facilities.

Based on these limitations of the study, we further intend to expand the research and try a deeper analysis of the EU member states by using a grouping analysis to observe the evolution of variables for countries in different stages of development.

\section{REFERENCES}

[1] Al-Mulali, U., Tang, C. F., Ozturk, I. (2015a): Estimating the environment Kuznets curve hypothesis: evidence from Latin America and the Caribbean countries. - Renewable and Sustainable Energy Reviews 50: 918-924.

[2] Al-Mulali, U., Saboori, B., Ozturk, I. (2015b): Investigating the environmental Kuznets curve hypothesis in Vietnam. - Energy Policy 76: 123-131.

[3] Allen, R. C. (2012): Backward into the future: the shift to coal and implications for the next energy transition. - Energy Policy 50: 17-23.

[4] Andrei, J., Panait, M., Ene, C. (2014): Environmental protection between social responsibility, green investments and cultural values. - Proceedings of the 3rd International Conference Competitiveness of Agro-Food and Environmental Economy, Bucharest, 7-12 November, pp. 179-187.

[5] Andrei, J., Mieila, M., Popescu, G., Nica, E., Cristina, M. (2016): The impact and determinants of environmental taxation on economic growth communities in Romania. Energies 9(11): 902.

[6] Andrei, J. V., Mieila, M., Panait, M. (2017): The impact and determinants of the energy paradigm on economic growth in European Union. - PloS One 12(3).

[7] Anghelache, C. (2011): Management of the environmental risk-an economic-social priority. - Theoretical and Applied Economics 3(3): 117-130.

[8] Apergis, N., Ozturk, I. (2015): Testing environmental Kuznets curve hypothesis in Asian countries. - Ecological Indicators 52: 16-22.

[9] Armeanu, D., Vintilă, G., Andrei, J. V., Gherghina, Ş. C., Drăgoi, M. C., Teodor, C. (2018): Exploring the link between environmental pollution and economic growth in EU28 countries: is there an environmental Kuznets curve? - PloS One 13(5).

[10] Bo, S. (2011): A literature survey on environmental Kuznets curve. - Energy Procedia 5: 1322-1325.

[11] Carson, R. T. (2010): The environmental Kuznets curve: seeking empirical regularity and theoretical structure. - Review of Environmental Economics and Policy 4(1): 3-23.

[12] Choi, I. (2001): Unit root tests for panel data. - Journal of International Money and Finance 20(2): 249-272.

[13] Commoner, B. (1972): The Environmental Cost of Economic Growth. Population, Resources and the Environment. - Government Printing Office, Washington, DC, pp. 339-63.

[14] Ciutacu, C., Chivu, L., Preda, D. (2005): The social responsibility of the company - a challenge for the contemporary world. - The Romanian Economics Magazine 2: 79.

[15] Cole, M. A., Rayner, A. J., Bates, J. M. (1997): The environmental Kuznets curve: an empirical analysis. - Environment and Development Economics 2(4): 401-416. 
[16] Cristea, M., Dobrota, C. E. (2017): Green energy for sustainable development in Romania's economy. - Revista de Chimie 68(6): 1473-1478.

[17] Dasgupta, S., Laplante, B., Wang, H., Wheeler, D. (2002): Confronting the environmental Kuznets curve. - The Journal of Economic Perspectives 16(1): 147-168.

[18] Dinda, S. (2004): Environmental Kuznets curve hypothesis: a survey. - Ecological Economics 49(4): 431-455.

[19] Du, L., Wei, C., Cai, S. (2012): Economic development and carbon dioxide emissions in China: provincial panel data analysis. - China Econ. Rev. 23: 371-384.

[20] Ene, C. (2011): Pesticides pollution of food-risks and implications for consumer protection. - The USV Annals of Economics and Public Administration 10(1): 46-55.

[21] Ene, C., Voica, M. C., Panait, M. (2017): Green Investments and Food Security: Opportunities and Future. - In: Mieila, M. (ed.) Measuring Sustainable Development and Green Investments in Contemporary Economies. IGI Global, Pennsylvania, USA, pp. 163-200.

[22] Ehrlich, P. R., Holdren, J. P. (1971): Impact of Population Growth. - Science 171: 12121217.

[23] Esteve, V., Tamarit, C. (2012): Threshold cointegration and nonlinear adjustment between $\mathrm{CO}_{2}$ and income: the environmental Kuznets curve in Spain, 1857-2007. Energy Economics 34(6): 2148-2156.

[24] Fisher, R. A. (1932): Statistical Methods for Research Workers. 4th Ed. - Oliver \& Boyd, Edinburgh.

[25] Fogel, R. W. (1987): Some Notes on the Scientific Methods of Simon Kuznets. National Bureau of Economic Research, Cambridge, MA.

[26] Granger, C. (1969): Investigating causal relations by econometric models and crossspectral Methods. - Econometrica 37(3): 424-438.

[27] Grossman, G. M., Krueger, A. B. (1991): Environmental Impacts of a North American Free Trade Agreement. - NBER Working Paper No. 3914.

[28] Im, K. S., Pesaran, M. H., Shin, Y. (2003): Testing for unit roots in heterogeneous panels. - Journal of Econometrics 115(1): 53-74.

[29] Jalil, A., Mahmud, S. F. (2009): Environment Kuznets curve for $\mathrm{CO}_{2}$ emissions: A cointegration analysis for China. - Energy Policy 37: 5167-5172.

[30] Kasperowicz, R. (2015): Economic growth and $\mathrm{CO}_{2}$ emissions: the ECM analysis. Journal of International Studies 8(3): 91-98.

[31] Kuzume, T. (2005): Intra-national and International PPP between cities of Japan and South Korea: Empirical evidence using panel unit root and panel cointegration tests. Paper presented at the 64th Annual Meeting of the Japan Society of International Economics, Ritsumeikan University.

[32] Kuznets, S. (1955): Economic growth and income inequality. - American Economic Review 45(1): 1-28.

[33] Lapinskienė, G., Peleckis, K., Slavinskaite, N. (2017): Energy consumption, economic growth and greenhouse gas emissions in the European Union countries. - Journal of Business Economics and Management 18(6): 1082-1097.

[34] Levin, A., Lin, C.-F., James Chu, C.-S. (2002): Unit root tests in panel data: asymptotic and finite-sample properties. - Journal of Econometrics 108(1): 1-24.

[35] Li, T., Wang, Y., Zhao, D. (2016): Environmental Kuznets curve in China: new evidence from dynamic panel analysis. - Energy Policy 91: 138-147.

[36] López, L. A., Arce, G., Zafrilla, J. E.(2013): Parcelling virtual carbon in the pollution haven hypothesis. - Energy Economics 39: 177-186.

[37] Maddala, G. S., Wu, S. (1999): A comparative study of unit root tests with panel data and a new simple test. - Oxford Bulletin of Economics and Statistics 61: 631-652.

[38] Marcu, N, Meghisan, G. M, Cristea, M. (2015): Environmental protection and mobile telecommunications services marketing strategies. - Proceedings of the Romanian Academy, Series B 17(1): 57-63. 
[39] Marcu, N., Cristea, M., Meghisan, G. M., Dascalu, D., Nasta, L. N. (2016): Impact of certain sectors of the economy on the chemical pollution of atmosphere in Romania. Revista de Chimie 67(6): 1195-1199.

[40] Nica, E. (2015): Public administration as a tool of sustainable development. - Journal of Self-Governance and Management Economics 3(4): 30-36.

[41] Panayotou, T. (1993): Empirical Tests and Policy Analysis of Environmental Degradation at Different Stages of Economic Development (No. 992927783402676). - International Labour Organization, Geneva.

[42] Panayotou T., Sachs J., Peterson, A. (1999): Developing Countries and Control of Climate Change: A Theoretical Perspective and Policy Implications. - CAER II Discussion Paper 45.

[43] Pirlogea, C., Cicea, C. (2012): Econometric perspective of the energy consumption and economic growth relation in European Union. - Renewable and Sustainable Energy Reviews 6(8): 5718-5726.

[44] Popescu, G. H., Comanescu, M., Dinca, Z. (2016): Economic growth and energy utilization in China. - Economics, Management and Financial Markets 11(2): 94.

[45] Popescu, G. H., Sima, V., Nica, E., Gheorghe, I. G. (2017): Measuring sustainable competitiveness in contemporary economies - insights from European economy. Sustainability 9(7): 1230.

[46] Saboori, B., Sulaiman, J. (2013): $\mathrm{CO}_{2}$ emissions, energy consumption and economic growth in association of Southeast Asian Nations (ASEAN) countries: a cointegration approach. - Energy 55: 813-822.

[47] Schmalansee, R., Stoker, T. M, Judson, R. A. (1998): World carbon dioxide emissions: 1950-2050. - The Review of Economics and Statistics 80(1): 15-17.

[48] Selden, T. M., Song, D. (1994): Environmental quality and development: is there a Kuznets curve for air pollution emissions? - Journal of Environmental Economics and management 27(2): 147-162.

[49] Shafik, N., Bandyopadhyay, S. (1992): Economic Growth and Environmental Quality: Time-Series and Cross-Country Evidence (Vol. 904). - World Bank Publications, Washington, DC.

[50] Shahbaz, M., Lean, H. H., Shabbir, M. S. (2012): Environmental Kuznets curve hypothesis in Pakistan: cointegration and Granger causality. - Renewable and Sustainable Energy Reviews 16: 2947-2953.

[51] Shahbaz, M., Ozturk, I., Afza, T., Ali, A. (2013): Revisiting the environmental Kuznets curve in a global economy. - Renewable and Sustainable Energy Reviews 25: 494-502.

[52] Sima, V., Georgiana, G. I. (2014): Analyze of environmental performance in Romania based on environmental performance index. - Annals-Economy Series 3: 101-104.

[53] Stern, D. I., Common, M. S., Barbier, E. B. (1996): Economic growth and environmental degradation: the environmental Kuznets curve and sustainable development. - World Development 24(7): 1151-1160.

[54] Sterpu, M., Soava, G., Mehedintu, A. (2018): Impact of Economic Growth and Energy Consumption on Greenhouse Gas Emissions: Testing Environmental Curves Hypotheses on EU Countries. - Sustainability 10(9): 3327.

[55] Su, B., Ang, B. W. (2016): Input-output analysis of CO emissions embodied in trade: Competitive versus non-competitive imports. - Energy Policy 56: 83-87.

[56] Tamazian, A., Rao, B. B. (2010): Do economic, financial and institutional developments matter for environmental degradation? Evidence from transitional economies. - Energy Economics 32(1): 137-145.

[57] Torras, M., Boyce, J. K. (1998): Income, inequality, and pollution: a reassessment of the environmental Kuznets curve. - Ecological economics 25(2): 147-160.

[58] Vasile, V., Balan, M. (2008): Impact of greenhouse effect gases on climatic changes. measurement indicators and forecast models. - Annales Universitatis Apulensis Series Oeconomica 2(10). 
[59] Voica, M. C., Panait, M., Radulescu, I. (2015): Green Investments-Between Necessity, Fiscal Constraints and Profit. - Procedia Economics and Finance 22: 72-79.

[60] Wawrzyniak, D. (2018): Testing environmental Kuznets curve in European Union countries. - Ekonomista 3: 318-334.

[61] World Bank (1992): World Development Report 1992: Development and the Environment. - Oxford University Press, New York.

[62] Zaman, G. (2005): The social-economic implications of the climate changes in Romania. - Romanian Journal of Economics 21(2): 116-134. 